\title{
Pembuatan Meja Bak Cuci Tangan Menggunakan Mutu Beton Sederhana dengan Memanfaatkan Limbah Olahan Rotan dan Sosialisasi Cuci Tangan 6 Langkah di Panti Asuhan Budi Mulya Kota Palangka Raya
}

\author{
Making a Handwashing Table Using Simple Quality Concrete Using Rattan Waste and 6 Steps
} Handwashing Socialization in Budi Mulya Orphanage Palangka Raya

Rida Respati*
Nirwana Puspasari
Hendra Putra Jaya
Ridho Saleh Silaban
Ari Widya Permana
Department of Civil Engineering,
Universitas Muhammadiyah
Palangkaraya, Palangka Raya, Central
Kalimantan, Indonesia
email:
rida.respati@umpalangkaraya.ac.id
Kata Kunci
Cuci tangan 6 langkah
Limbah olahan rotan
Sosialisasi
Virus corona
Keywords:
Wash hands 6 steps
Rattan processed waste
Socialization
Corona virus

\begin{abstract}
Abstrak
Perkembangan virus corona atau Covid-19 di Kalimantan Tengah saat ini semakin mengkhawatirkan. Seluruh wilayah di provinsi ini kini berstatus zona merah. Penularan ini sangat cepat penyebarannya, sehingga kami dan tim melakukan sosialisasi kepada masyarakat di Panti Asuhan Budi Mulya Kota Palangka Raya untuk menerapkan 6 langkah cuci tangan yang dianjurkan untuk membunuh virus covid 19 yang menempel di jari jemari kita. Mencuci tangan dengan sabun menjadi salah satu tindakan sanitasi untuk pencegahan penyakit. Bahkan WHO juga menganjurkan 6 langkah dalam mencuci tangan telapak tangan, telapak punggung tangan, sela-sela jari, punggung tangan, jempol dan ujung jari. Cara cuci tangan yang terakhir bersihkan sabun dengan air yang mengalir dan keringkan. Untuk mendukung program cuci tangan 6 langkah, kami dengan tim bekerjasama dengan Pimpinan panti untuk membuat meja tempat bak penampungan air yang digunakan untuk mencuci tangan. Meja tersebut dibuat permanen, terbuat dari beton bertulang, yang komposisi campuran beton bertulang tersebut dicampur dengan limbah olahan rotan yang sudah tidak terpakai, sebagai pengganti serat beton. Adapun campuran limbah rotan yang digunakan adalah $0,25 \%$ dari total volume beton.
\end{abstract}

\begin{abstract}
The development of coronavirus or Covid-19 in Central Kalimantan is currently increasingly worrying. All areas in this province are now in red zone status. This transmission is very fast spreading, so we are doing outreach to the community at Budi Mulya Orphanage, Palangka Raya City, implementing 6 recommended handwashing steps to kill the Covid 19 virus that sticks to our fingers. Washing hands with soap is one of the sanitation measures to prevent disease. Even WHO also recommends 6 steps in washing the palms of hands, the palms of backs of hands, between the fingers, the backs of hands, the thumbs, and the tips of fingers. The last method of washing hands is to clean soap with running water and dry it. To support the 6-step handwashing program, we are working with the orphanage's leadership to make a table for a water storage basin used for washing hands. The table is made permanent, made of reinforced concrete, whose composition of the reinforced concrete mixture is mixed with processed rattan waste that is no longer used as a substitute for concrete fiber. The rattan waste mixture used was $0.25 \%$ of the total volume of concrete.
\end{abstract}




\section{PENDAHULUAN}

Virus Corona Covid-19 semakin mengancam Indonesia karena penyebarannya begitu mudah, cepat dan tidak memandang usia. Warga pun diminta untuk disiplin dalam menjaga kesehatan dan juga kebersihan demi terhindari dari virus berbahaya ini. Peningkatan kasus virus corona bukan hanya terjadi di Indonesia, tapi juga berbagai belahan dunia. Saat ini, ada tiga negara di luar China yang terdampak paling parah wabah ini, yaitu Amerika Serikat, Italia, dan Spanyol (Purnama \& Susanna, 2020).

Hingga kini, belum ditemukan vaksin yang dapat mengatasinya. Saat para peneliti melakukan rangkaian uji tes vaksin yang dapat digunakan sebagai penawar virus, maka kita harus waspada dan menerapkan gaya hidup sehat agar terhindar dari virus corona (Bartsch et al., 2020). Pembatasan aktivitas di luar rumah dan menghindari kerumunan adalah hal yang harus dilakukan. Bahkan pemerintah Indonesia juga menegaskan untuk lakukan social distancing disertai proses belajar, bekerja, dan beribadah di rumah. Hal ini sangat penting dilakukan agar tidak semakin banyak orang yang terpapar virus Corona (Güner et al., 2020).

Perkembangan virus corona atau yang sering disebut dengan Covid-19 di Kalimantan Tengah semakin mengkhawatirkan. Seluruh wilayah di provinsi ini kini berstatus zona merah. Satuan Gugus Tugas COVID-19 Provinsi Kalimantan Tengah kembali memperbarui data pasien positif Corona di Provinsi Kalimantan Tengah. Data tanggal 16 September 2020, jumlah pasien positif Corona di Kalteng bejumlah 3.086 jiwa, dalam perawatan 553 jiwa, sembuh 2.411 jiwa dan meninggal sebanyak 122 jiwa.

Kita tahu bahwa penyakit ini sangat berbahaya, tidak hanya orang tua, dewasa maupun anak-anak, tetapi bayi pun bisa tertular penyakit ini. Sampai dengan saat ini belum ditemukan obat untuk penyembuhan penyakit tersebut, hal yang harus kita upayakan adalah dengan rajin mencuci tangan dan selalu menjaga kebersihan (Alzyood et al., 2020; Skolmowska et al., 2020).

Beberapa upaya pemerintah telah dilakukan untuk memutus penyebaran virus ini diantaranya adalah melakukan kerja dari rumah (WFH), menyemprotkan desinfektan, Physical Distancing (menjaga jarak), Pembatasan Sosial Berskala Kecil (PSBK) bahkan Pembatasan Sosial Berskala Besar (PSBB). Adapun himbauan pemerintah terhadap masyarakat seperti, rajin mencuci tangan, menggunakan hand sanitizer, kenakan masker, hindari bersentuhan, jangn sentuh area wajah, etika batuk mapun bersin, hindari berbagi barang pribadi, bersihkan perabot rumah, physical distancing, selalu mencuci bahan makanan dan meningkatan imunitas tubuh (Jandrić et al., 2020).

Meskipun pemerintah selalu menghimbau, akan tetapi angka positif Covid-19 terus bertambah setiap harinya. Ketidakpahaman masyarakat akan pentingnya selalu menjaga kebersihan kurang di mengerti, merasa tubuh tidak ada keluhan, tetap aktif beraktifitas, tanpa menyadari bahwa mereka bisa saja pembawa (carrier) virus tersebut, sehingga apabila daya tahan tubuh/imunitas menurun sangat mudah sekali tertular terutama para lansia atau yang sudah berusia lanjut (Norhapifah et al., 2020). Penularan ini sangat cepat penyebarannya, sehingga disini kami dan tim ingin melakukan sosialisasi kepada masyarakat di Panti Asuhan Budi Mulya Jl. R.T.A. Milono Kota Palangka Raya untuk menerapkan 6 langkah cuci tangan yang dianjurkan untuk membunuh virus covid 19 yang menempel di jari jemari kita.

Kementerian Kesehatan menetapkan tanggal 15 Oktober sebagai Hari Cuci Tangan Pakai Sabun Sedunia (HCTPS). Mencuci tangan dengan sabun menjadi salah satu tindakan sanitasi untuk pencegahan penyakit. Bahkan WHO juga menganjurkan 6 langkah dalam 
mencuci tangan telapak tangan, telapak punggung tangan, sela-sela jari, punggung tangan, jempol dan ujung jari. Cara cuci tangan yang terakhir bersihkan sabun dengan air yang mengalir dan keringkan (Pusat Data dan Informasi Kementerian Kesehatan Republik Indonesia, 2014).

Berdasarkan hal tersebut, perlu dilakukan upaya edukasi terkait 6 langkah cuci tangan yang dianjurkan oleh WHO/Kemenkes sebagai upaya untuk perubahan perilaku sehingga nantinya dapat meningkatkan derajat kesehatan masyarakat di Panti Asuhan Budi Mulya Kota Palangka Raya. Ketersedian air tentunya akan memudahkan mereka untuk terus melakukan perilaku hidup bersih dan sehat yang nantinya kita ajarkan sehingga perilaku mereka dapat berkelanjutan baik di rumah maupun di lingkungan sekitar.

Berdasarkan hasil penelitian sebelumnya, yaitu tentang Pemanfaatan limbah olahan rotan sebagai serat beton dimana salah satu penyebab keruntuhan pada bangunan dikarenakan kerusakan beton bertulang akibat korosi yang disebabkan oleh lepas atau retaknya selimut beton yang berfungsi sebagai pelindung tulangan (Respati \& Santoso, 2020). Peningkatan ketahanan pengelupasan (spalling) dan retak pada selimut beton akan membantu menghambat korosi pada besi tulangan dari kondisi lingkungan yang berpotensi korosi sehingga diharapkan dengan terlindungnya tulangan besi dalam beton, mencegah terjadi korosi atau patah terhadap tulangan (Fahirah, 2007).

Untuk mendukung program cuci tangan 6 langkah, kami dengan tim bekerjasama dengan Pimpinan panti asuhan Budi Mulya Palangka Raya untuk membuat meja tempat bak penampungan air yang digunakan untuk mencuci tangan. Meja tersebut dibuat permanen, dimana terbuat dari beton bertulang, yang komposisi campuran beton bertulang tersebut dicampur dengan limbah olahan rotan yang sudah tidak terpakai, sebagai pengganti serat beton. Adapun campuran limbah rotan yang digunakan adalah 0,25\% dari total volume beton. Dari permasalahan di atas, maka tim mengambil kesimpulan untuk mencegah/menghindari penyebaran virus corona maka tim mencoba menerapkan ilmu yang didapat dengan membangun meja tempat penampungan air untuk cuci tangan dengan memanfaatkan limbah olahan rotan di Panti Asuhan Budi Mulya Jl. R.T.A. Milono Palangka Raya serta melakukan edukasi kesehatan untuk membiasakan hidup bersih dimana salah satu cara yang dilakukan adalah cuci tangan 6 langkah.

Meja penampungan air tersebut akan dibuat permanen, mengunakan pondasi telapak ukuran $80 \times 80 \mathrm{~cm}$ sebagai lantai kerja sekaligus pondasi, kemudian kaki meja di cor mengunakan besi tulangan diameter $10 \mathrm{~mm}$, dengan tinggi $1 \mathrm{~m}$ dari permukaan tanah. Untuk plat lantai meja di cor mengunakan besi $10 \mathrm{~mm}$ dengan tebal $10 \mathrm{~cm}$ dan ukuran lebar $60 \times 60 \mathrm{~cm}$. Untuk bak penampungan air terbuat dari material plastik, dengan kapasitas air $250 \mathrm{~L}$. Untuk mencegah terinfeksi virus corona, maka beberapa hal yang harus kita lalukan adalah:

\section{Rajin Mencuci Tangan}

Walau terdengar umum, namun mencuci tangan adalah pangkal kebersihan dan kesehatan. Tangan adalah sumber kuman dan bakteri yang dapat menyebabkan beragam penyakit. Cuci tangan minimal 20 detik dengan menggunakan sabun, dan air mengalir. Langkah ini efektif membunuh kuman dan bakteri, termasuk virus corona. Cuci tangan menjadi salah satu cara mencegah penyebaran virus corona yang sangat diremondasikan, termasuk oleh WHO.

\section{Memakai Masker}

Meskipun virus corona tidak menular lewat udara, upayakan untuk menggunakan masker agar tetap terlindungi dari virus. Jika kondisi Anda sehat, maka 
masker kain sudah cukup aman untuk dipakai. Tapi jika kamu dalam kondisi kesehatan yang kurang baik, maka upayakan untuk menggunakan masker medis yang memiliki ketebalan 3 lapis.

\section{Menghindari Bersentuhan}

Berpelukan, dan berjabat tangan, adalah hal yang harus dihindari. Dengan menghindari kontak kulit maka tak ada kemungkinan perpindahan virus dan kuman yang terjadi.

4. Jangan Menyentuh Area Wajah

Virus corona bisa menyerang tubuh lewat area segitiga wajah seperti mulut, mata, dan hidung. Jadi, hindari untuk menyentuhnya agar tidak ada kemungkinan masuknya virus corona ke tubuh.

5. Etika Bersin dan Batuk

Virus corona bisa menular lewat droplet. Jadi saat bersin dan batuk, tutup dengan tisu atau lipatan tangan agar virus tidak menyebar ke orang lain. Jangan lupa untuk segera mencuci tangan setelahnya.

6. Menghindari Berbagi Barang Pribadi

Bukan pelit, tapi ini demi kesehatan bersama. Perlu diingat jika virus corona dapat bertahan pada permukan hingga tiga hari. Oleh sebab itu, usahakan untuk menggunakan barang pribadi dan tidak memakainya secara bergantian.

7. Membersihkan Perabot Rumah

Selain menjaga kebersihan tubuh, Anda juga harus menjaga kebersihan rumah. Jangan lupa untuk gunakan cairan desinfektan untuk membersihkannya secara teratur sehingga tak ada kuman dan virus penyebab penyakit yang bersarang di rumah.

\section{Physical Distancing}

Hindari kerumunan dan jaga jarak minimal 1 meter dengan orang lain. Langkah ini bisa diterapkan saat berada di tempat umum atau luar ruangan sehingga kamu bsa mencegah terpapar virus corona.

9. Selalu Mencuci Bahan Makanan

Jangan lupa untuk mencuci bahan makanan sebelum disantap atau disimpan di dalam lemari pendingin. Buah-buahan dan sayuran bisa dibersihkan dengan larutan hidrogen peroksida atau cuka putih yang sangat aman digunakan untuk makanan.

10. Meningkatkan Imunitas Tubuh

Hindari stres, makan makanan bergizi yang kaya vitamin dan mineral serta lakukan olahraga ringan agar badan tetap fit selama WFH di rumah. Saat imunitas tubuh baik, maka akan memperkecil kemungkinan Anda untuk terkena virus corona yang membahayakan kesehatan.

\section{METODOLOGI}

Persiapan kegiatan ini dimulai dengan melakukan koordinasi dan meminta ijin dengan Pimpinan Panti Asuhan Budi Mulya Jl. R.T.A. Milono Kota Palangka Raya. Pengurusan ijin dan koordinasi dilaksanakan pada tanggal 15 Juni 2020. Setelah mendapatkan ijin, kemudian tim pelaksana kegiatan mempersiapkan diri dan mempersiapkan sarana dan prasarana untuk pelaksanaan kegiatan tersebut agar kegiatan berjalan dengan lancar.

Kami dan tim juga pihak panti bersama-sama turun langsung kelapangan untuk melakukan lokasi pembuatan tempat cuci tangan. Tenaga yang mengerjakan adalah penduduk lokal dengan arahan yang kami berikan. Disamping pembuatan bak pencucian tangan, kami juga memberikan sosialisasi yang berkaitan dengan perilaku hidup bersih di rumah, sehingga secara mandiri mampu mencegah penyakit termasuk covid 19, meningkatkan kesehatan serta berperan aktif dalam mewujudkan lingkungan sehat. 
Simulasi yang akan diberikan dan diikuti oleh warga adalah dengan cara mencuci tangan pakai sabun dengan benar mengikuti langkah-langkah yang telah ditetapkan World Hearth Organization (WHO), yaitu Enam Langkah Cuci Tangan:

1. Menuangkan cairan hand soap pada telapak tangan kemudian usap dan menggosok kedua telapak tangan secara lembut dengan arah memutar

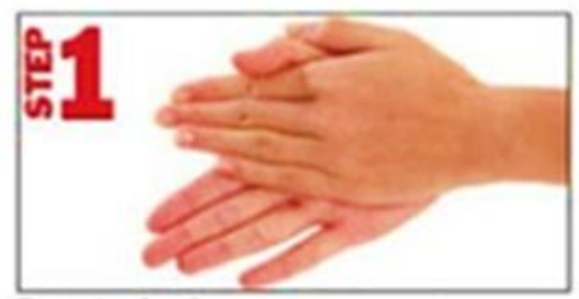

Gambar 1. Menggosok kedua telapak Tangan

2. Mengusap dan menggosok juga kedua punggung tangan secara bergantian

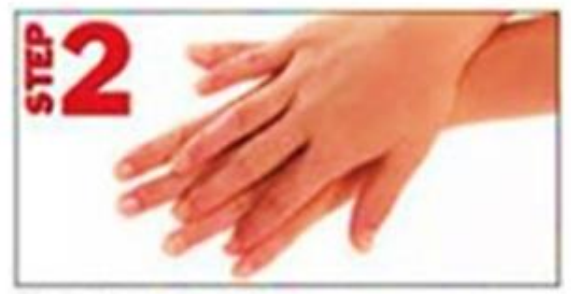

Gambar 2. Menggosok punggung Tangan

3. Menggosok Sela-sela jari

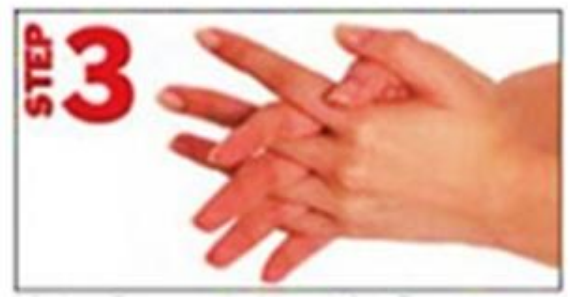

Gambar 3. Menggosok Sela-sela Jari Tangan

4. Membersihkan ujung jari secara bergantian dengan posisi saling mengunci

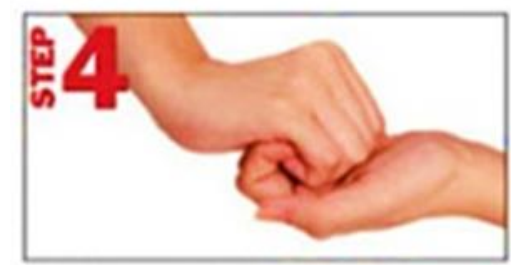

Gambar 4. Membersihkan ujung jari Tangan
5. Menggosok dan memutar kedua ibu jari secara bergantian

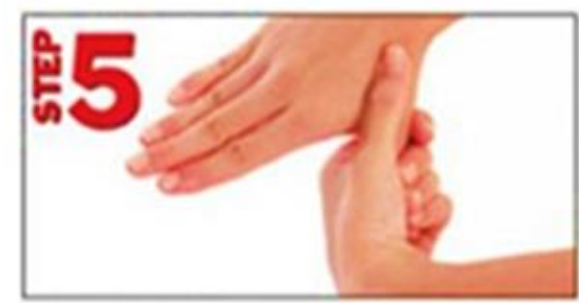

Gambar 5. Menggosok dan memutar kedua ibu jari Tangan

6. Meletakan ujung jari ketelapak tangan kemudian menggosok perlahan

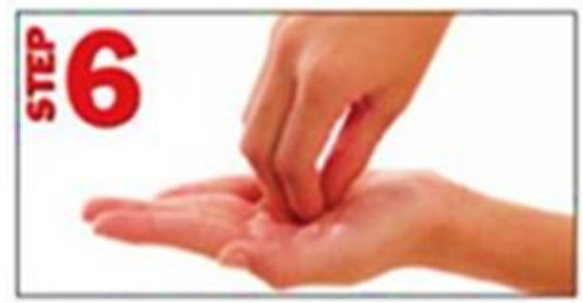

Gambar 6. Menggosok ujung jari Tangan

\section{HASIL DAN PEMBAHASAN}

Koordinasi dengan Pihak Panti Budi Mulya

Sebelum memulai kegiatan, kami mengadakan koordinasi dengan pihak panti, dengan mengemukakan niat kedatangan kami untuk menyediakan bak cuci tangan dan sosialisasi cuci tangan 6 langkah, waktu pelaksanaan sosialisasi dan penempatan bak cuci tangan tersebut.

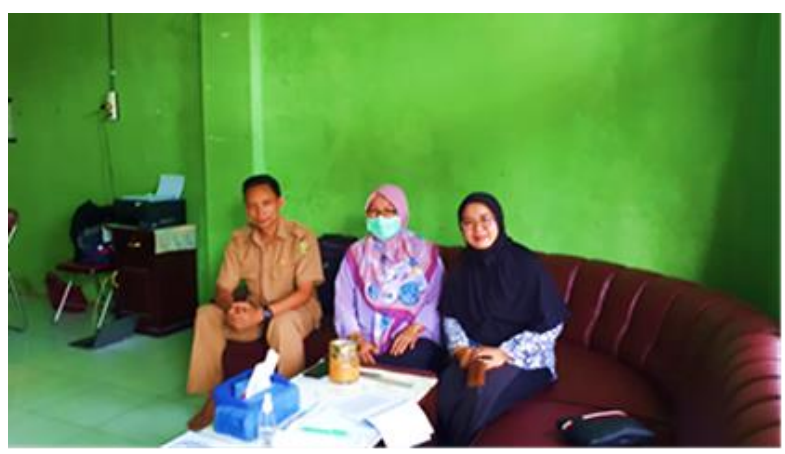

Gambar 7. Koordinasi dengan Pihak Panti Asuhan

Perilaku seseorang dapat dipengaruhi oleh beberapa faktor seperti pengetahuan, sikap, motivasi, dan 
lingkungan. Salah satu bentuk perilaku yang terdapat dalam hal kesehatan yaitu kebersihan diri. Bentuk perilaku hidup sehat adalah dengan menjaga kebersihan diri, salah satunya bentuk kebersihan diri yang paling mudah yaitu mencuci tangan.

Dengan membuat meja bak pencucian tangan di tempat yang strategis, (berkonsultasi dengan pimpinan Panti) diharapkan anak-anak/masyarakat akan terbiasa hidup bersih dan dapat mempraktikan 6 langkah cara mencuci tangan yang benar sehingga dapat menekan/memutus mata rantai penyebaran covid 19 sehingga tidak ada lagi masyarakat/warga yang tertular penyakit ini, karena kita tahu bahwa penyakit ini sangat berbahaya dan belum ada obatnya.

Pembuatan Bak Cuci Tangan Menggunakan Beton Sederhana di campur Serat Rotan

Beton adalah campuran agragat halus, agregat kasar, semen dan air. Dalam pembuatan bak cuci tangan mengunakan beton yang di campur dan campuran serat olahan rotan, yaitu sebanyak $0,3 \%$ dari berat semen. Sehingga dari 1 zak semen seberat $40 \mathrm{Kg}$ membutuhkan rotan seberat $0,3 \% \times 40 \mathrm{Kg}=0,12 \mathrm{Kg}=120 \mathrm{~g}$.
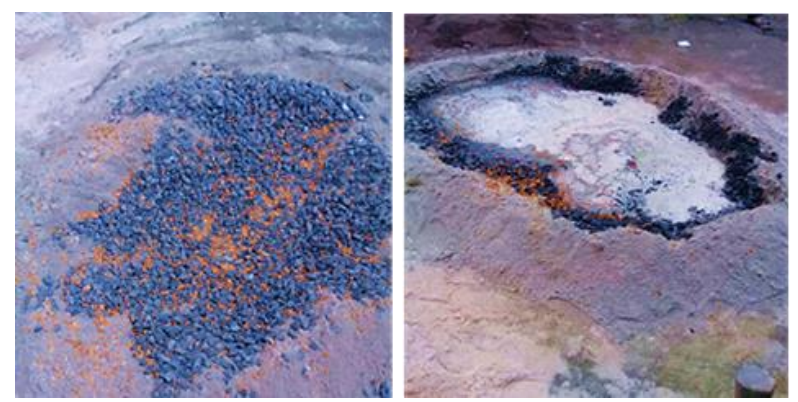

Gambar 8. Pencampuran rotan dengan beton

Kemudian pembuatan pondasi dan kaki meja dari besi dan pemasangan bekisting dan kemudian dicor mengunakan beton yang sudah $\mathrm{d}$ campur dengan rotan olahan.
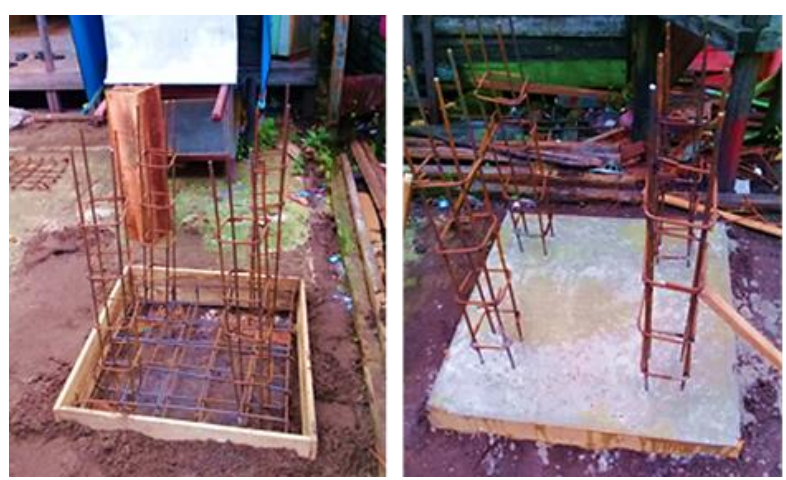

Gambar 9. Pembuatan pondasi

Setelah tiang/kaki meja dicor beton, dan beton ditunggu hingga kering, barulah dipasang tandon air untuk anakanak cuci tangan.
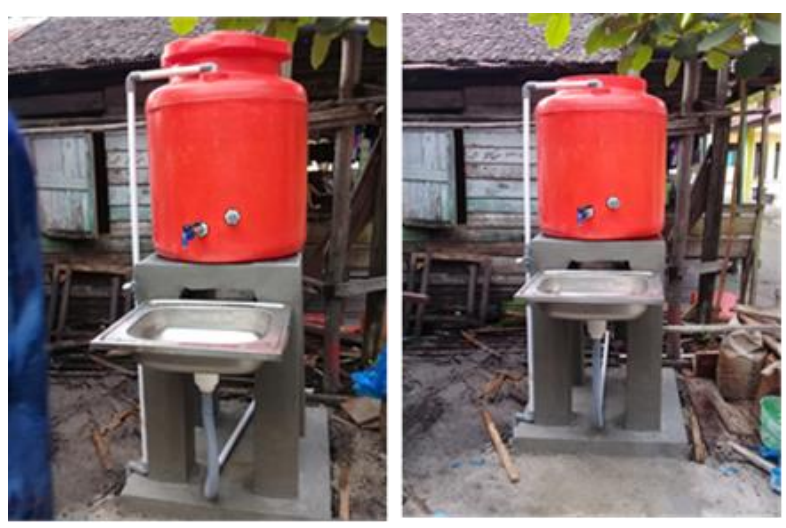

Gambar 10. Bak cuci tangan dengan Beton Campuran Limbah Rotan

Meja dibuat menggunakan sisa limbah rotan yang sudah tidak digunakan, dicampur dengan beton mutu sederhana.

Sosialisasi 6 Langkah Mencuci Tangan

Kegiatan sosialisasi cuci tangan dilakukan pada bulan September 2020 yang dihadiri oleh anak-panti asuhan, Ketua Yayasan, dan para pengurus panti asuhan Budi Mulya. 


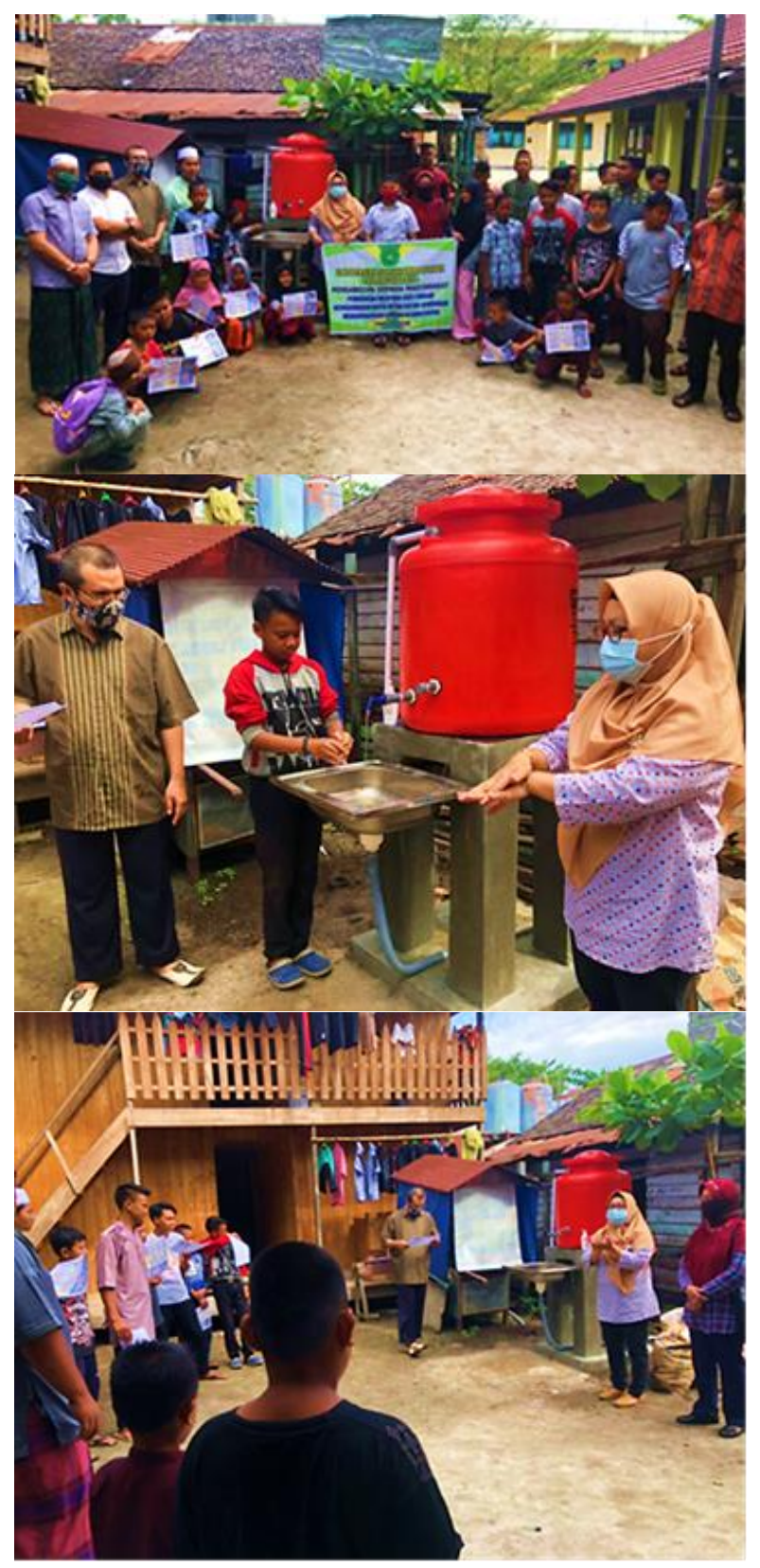

Gambar 11. Kegiatan Sosialisasi Cuci Tangan

\section{KESIMPULAN}

Hasil penelitan tentang pemanfaatan limbah olahan rotan bisa diaplikasikan dalam struktur beton sederhana dan penerapannya dalam pembuatan meja bak cuci tangan yang pembuatannya di Panti Asuhan Budi Mulya Jl. R.T.A. Milono Palangkaraya. Pelaksanaan Pengabdian masyarakat dapat diselesaikan sesuai harapan, banyaknya anak-anak panti yang masih kecil membuat pelaksanaan sosialisasi berjalan panjang karena membutuhkan kesabaran dalam mengajari mereka. Panti Asuhan ini mempunyai anak asuh kurang lebih 80 anak, untuk kedepannya apabila pihak LP2M ingin mengadakan pengabdian masyarakat, alangkah baiknya agar bisa melaksanakan kegiatan di lingkungan panti ini karena walaupun letaknya di dalam kota tetapi masih belum mendapat perhatian lebih dari pemerintah kota maupun provinsi.

\section{UCAPAN TERIMA KASIH}

Dengan selesainya kegiatan pengabdian masyarakat ini kami mengucapkan banyak terimakasih kepada Lembaga Penelitian dan Pengabdian Masyarakat (LP2M) UM Palangkaraya, yang telah memberikan dukungan berupa dana sehingga kegiatan pengabdian masyarakat yang kami lakukan ini dapat terlaksana dengan baik dan lancar.

\section{REFERENSI}

Alzyood, M., Jackson, D., Aveyard, H., Brooke, J. 2020. COVID-19 reinforces the importance of handwashing. Journal of Clinical Nursing. Epub ahead of print. https://dx.doi.org/10.1111/jocn.15313

Bartsch, S.M., O'Shea, K.J., Ferguson, M.C., Bottazzi, M.E., Wedlock, P.T., Strych, U., McKinnell, J.A., Siegmund, S.S., Cox, S.N., Hotez, P.J., Lee, B.Y. 2020. Vaccine Efficacy Needed for a COVID-19 Coronavirus Vaccine to Prevent or Stop an Epidemic as the Sole Intervention. American Journal of Preventive Medicine. 59(4):493-503.

https://dx.doi.org/10.1016/j.amepre.2020.06. 011

Güner, R., Hasanoğlu, I., Aktaş, F. 2020. COVID-19: Prevention and control measures in community. Turkish Journal of Medical Sciences. 50(3):571-577.

https://dx.doi.org/10.3906/sag-2004-146

Fahirah, F. 2007. Korosi pada Beton Bertulang dan Pencegahannya. Jurnal Smartek. 5(3):190-195.

Jandrić, P., Hayes, D., Truelove, I. 2020. Teaching in the Age of Covid-19. Postdigital Science and 
Education.

2:1069-1230.

https://doi.org/10.1007/s42438-020-00169-6

Purnama, S.G., Susanna, D. 2020. Hygiene and Sanitation Challenge for COVID-19 Prevention in Indonesia. Kesmas: National Public Health Journal. Special Issue(1):6-13. http://dx.doi.org/10.21109/kesmas.v15i2.39 32

Pusat Data dan Informasi Kementerian Kesehatan Republik Indonesia. 2014. Perilaku Mencuci Tangan Pakai Sabun di Indonesia: 6 Langkah Mencuci Tangan. Jakarta: Kementerian Kesehatan Republik Indonesia.

Norhapifah, H., Kholifah, S., Putri, D.M., Selviyana. 2020. Pentingnya Menjaga Kesehatan Jiwa Saat Pandemi Covid-19 Dilingkungan Masyarakat RT 30 Kelurahan Air Hitam, Samarinda, Kalimantan Timur. Jurnal Abdimas Medika. 1(2):1-7.

Respati, R., Santoso, A.I. 2020. The Use of Rattan Processed Waste as A Complement in Fiber Concrete. Journal of Physics: Conference Series. 1477:052015. http://dx.doi.org/10.1088/17426596/1477/5/052015

Skolmowska, D., Głąbska, D., Guzek, D. 2020. Hand Hygiene Behaviors in a Representative Sample of Polish Adolescents in Regions Stratified by COVID-19 Morbidity and by Confounding Variables (PLACE-19 Study): Is There Any Association? Pathogens. 9(12):1011. https://doi.org/10.3390/pathogens9121011 